\title{
DAKWAH DAN PERUBAHAN SOSIAL DALAM PERSPEKTIF TEORI SOSIOLOGI
}

\author{
H. M. Bahri Ghazali ${ }^{1}$ an Muhamad Jamil² \\ UIN Raden Intan Lampung, STAI Yayasan Islam Tarbiyah Padang \\ m.bahrighazali@radenintan.ac.id, jamiljaey@gmail.com
}

\begin{abstract}
Da'wah not only conveys religious messages, but it also organizes social life. For this reason, da'wah is faced with the performance of theoretical analysis that deals directly with social theories. One theory that helps the performance of $d a^{\prime}$ wah is the theory of social change. This article explains that between da'wah and the theory of social change is a necessity to achieve the goal of changing the condition of a society that is the object of da'wah. Da'wah as an activity of an individual or group of people integrated in a series of Islamic religious doctrines-material activities, needs to touch pure sciences (pure sciences) as the basis for laying various approaches, strategies or methods, and other elements of da'wah.
\end{abstract}

\section{Key Words : Da'wah, Social Change}

\begin{abstract}
Abstrak
Dakwah bukan hanya menyampaikan pesan agama, melainkan ia juga menata kehidupan social. Untuk itu dakwah dihadapkan kepada kinerja analisis-teoritik yang berhubungan lansung dengan teori-teori social.Salah satu teori yang membantu kinerja dakwah adalah teori perubahan social.Artikel ini menjelaskan bahwa antara dakwah dengan teori perubahan social merupakan suatu keniscayaan untuk mencapai tujuan perubahan kondisi suatu masyarakat yang menjadi objek dakwah. Dakwah sebagai aktivitas individu atau sekelompok orang yang terintegrasi dalam suatu rangkaian doktrin agama islamaktivitas-materi, perlu sentuhan ilmu-ilmu murni (pure sciences)sebagai dasar peletakan berbagai pendekatan, strategi atau metode, serta unsur dakwah lainnya.
\end{abstract}

\section{Kata Kunci : Dakwah, Perubahan Sosial}

\section{Pendahuluan}

"Masyarakat dan kebudayaan berubah! Tiap kelompoknya, tiap lembaganya mengalami perubahandan segala perubahan itumengakibatkan perubahan lainlagi secara timbal balik dan amat berbelit-belit. ${ }^{3}$

Menarik sekali pernyataan yang dinyatakan oleh Mayor Polak dalam bukunya "Sosiologi Suatu Pengantar Ringkas" di atas.Karena kenyataan sekarang adalah dinamisasi dari masyarakat sudah menjadi kajian dari berbagai kalangan ilmuwan sosiologi. Gerak perubahan masyarakat dari satu titik ke titik lain menjadi sangat menarik untuk diteliti apalagi perubahan itu tidak berhenti

1 Universitas Islam Negeri Raden Intan Lampung, Jl. Letkol H. Endro Suratmin, Sukarame, Bandar Lampung, Indonesia: m.bahrighazali@radenintan.ac.id.

2 Sekolah Tinggi Agama Islam Yayasan Tarbiyah Islamiyah Padang. jamiljaey@gmail.com.

3 Mayor Polak, Sosiologi Suatu Pengantar Ringkas, (PT. Ichtiar Baru. Jakarta, 1979), h. 379 
pada satu titik melainkan saling menyebar hingga menemukan bentuk baru dari realitas social tidak terkecuali realitas dakwah.

Dakwah merupakan manifestasi ajaran islam dan menjadi fenomena tersendiri dalam kehidupan masyarakat. Fenomena dakwah ini kemudian dapat diamati sebagai upaya mencapai suatu perubahan-perubahan yang dinginkan oleh dakwah itu sendiri.Perubahan social dimaksud berhubungan dengan aktivitas dakwah merupakan kajian perubahan social yang mesti mendapatkan tempat baru dalam keilmuan dakwah maupun sosiologi.Kedua konsep ini saling menguntungkan disebabkan dakwah mesti dibantu oleh ilmu-ilmu social untuk mencapai tujuan-tujuan dakwah secara efektif.

Berbagai teori dikedepankan untuk menguji kelayakan perubahan sosial menjadi kajian sosial.Namun teori tersebut tetap saja berangkat dari perspektif aliran sosiologi yang dimiliki oleh para ilmuwan.Sebut saja aliran funsionalis, yang berpendapat bahwa perubahan soial merupakan perubahan yang terjadi dalam struktur dan fungsi masyarakat.Akan tetapi sudut pandang dari satu perspektif saja belum cukup untuk memberikan pemahaman tentang hakikat sosial sebagai kajian sosial.

Untuk memberikan pemahaman tentang perubahan sosial sebagai kajian sosial, perlu dilihat aspek-aspek sekaligus menjadi batasan dalam artikel ini, yaitu; bagaimana dakwah dan perubahan sosial dalam perspektif teori sosiologi?

\section{Dakwah Dan Perubahan Sosial Dalam Perspektif Teori Sosiologi}

Secara bahasa kata dakwah yang ada dalam al-Qur'an bermakna; seruan, panggilan, dan permohonan. Sifat dari kata-kata tersebut adalah aktivitas, maka dakwah adalah aktivitas/perilaku manusia. Secara istilah pengertian dakwah berkembang sesuai dengan perkembangan keilmuan dakwah itu sendiri.

Memang tidak dapat dipungkiri bahwa secara aplikatif dakwah telah ada sejak Rasulullah Saw.Menyampaikan ajaran Islam.Tetapi keilmuan dakwah baru berkembang pada masa sekarang ini.Maka, pengertian dakwah setidaknya harus merujuk kepada al-Qur'an dan tujuan agama Islam, bukan golongan atau firqah yang diyakini.Hal ini untuk menghindari kerancuan pengertian dakwah oleh berbagai firqah yang ada.Dakwah dapat dimaknai segala aktivitas manusia yang bertujuan untuk memanggil/menyeru manusia lainnya kepada jalan Allah (doktrin Islam) dengan menggunakan berbagai pendekatan dan metode yang baik supaya manusia yang diseru atau dipanggil tersebut mampu hidup selaras dan harmoni, serta sejahtera dunia dan akhirat. ${ }^{4}$

Pengertian di atas merujuk kepada kondisi yang dialami oleh masyarakat, baik kondisi spritual-psikis, maupun material-fisik masyarakat yang menjadi objek dakwah. Dakwah tidak hanya mementingkan perubahan spritual-psikis umat saja dari, seperti; dari tidak beriman -menjadi beriman, tidak shalat

4 Moh. Ali Aziz, Ilmu Dakwah,( Jakarta: Prenada Media Group,2009), h. 6. Bandingkan dengan pendapat Syekh Muhammad Abu Al-Fattah Al-Bayanuny, Ilmu Dakwah; Prinsip Dan Kode Etik, (Penterj, Dedi Junaedi, Jakarta: Akademika Presindo, 2010), h. 4.Asep Muhiddin, Dakwah Dalam Perspektif Al-Qur'an, (Bandung, Pustaka Setia, 2002), h.39.Salmadanis, Da'i Dan Kepemimpinan(Jakarta, The Minangkabau Foundation, 2004), h. 24. Bandingkan juga dengan pendapat Enjang As dan Aliyudin, Dasar-Dasar Ilmu Dakwah: Pendekatan Filofofis dan Praktis (Widya Padjadjaran, 2009), h. 73. 
menjadi - megerjakan shalat. Tetapi jauh dari itu mengupayakan orang miskin yang tidak beriman-menjadikan miskin beriman, dan seterusnya miskin beriman-menjadi kaya beriman-kemudian meneruskannya kepada umat yang lainnya.

Upaya mewujudkan padanan seperti di atas tidak akan mencapai sasarannya jika da'i mengabaikan analisis sosial untuk menetapkan pendekatan, strategi, dan metode yang tepat. Teori sosial yang bisa membantu dimaksud adalah teori perubahan sosial.

Kata yang tidak asing ketika kita membaca buku-buku sosiologi adalah "perubahan sosial".Sekilas memang dua kata tersebut terdengar aneh namun sebenarnya inti dari sosiologi itu terletak pada "perubahan sosial". Hal ini disebabkan oleh objek kajian sosiologi adalah masyarakat yang dilihat dari sudut hubungan antar manusia, dan proses yang timbul akibat hubungan manusia di dalam masyarakat. ${ }^{5}$

Proses hubungan yang timbul akibat hubungan manusia di dalam masyarakat akan menimbulkan berbagai potensi-potensi yang muncul, sehingga menjadi objek kajian yang banyak ditelaah oleh para ilmuwan. Untuk membuktikan asumsi ini, tentu dibuktikan dengan tinjauan secara terminologi tentang Perubahan Sosial.

Pembatasan yang diberikan oleh para ahli di atas terdapat kekurangan antara ahli satu dengan ahli yang lain. Karena terkadang menekankan pada beberapa bagian dari apa yang disebut dengan masyarakat. Seperti; Selo Sumarjan yang menekankan perubahan pada kelompok masyarakat, "Samuel Koenig yang menekankan definisinya pada pola-pola kehidupan manusia, Mac Iver yang menekankan pada perubahan hubungan masyarakat, serta Kingsley Davis yang menekankan pada struktur dan fungsi masyarakat. Definisi Gillin dan Gillin sepertinya mendekati pemahaman bahwa perubahan sosial itu terletak pada kondisi sesuatu seperti geografi, ideology, kebudayaan, dan lain sebagainya.

Berbeda lagi dengan Sztompka, menurutnya konsep dasar perubahan sosial mencakup tiga gagasan: (1) perbedaan, (2) pada waktu berbeda), (3) di antara keadaan system sosial yang sama. Kemudian Sztompka mengutip definisi dari Hawley sebagai berikut; 'Perubahan sosial adalah setiap perubahan yang tak terulang dari system sosial sebagai satu kesatuan'. ${ }^{7}$

\section{Teori-Teori Perubahan Sosial}

Dalam konteks keseharaian, sering kita mendengar istilah "tiada yang abadi selain perubahan". Hal ini menandakan begitu akrabnya sebuah perubahan dalam kehidupan ummat manusia dan alam ini.Untuk itu kecenderungan terjadinya perubahan-perubahan sosial merupakan gejala yang wajar yang timbul dari pergaulan hidup manusia di dalam masyarakat. Perubahanperubahan sosial akan terus berlangsung sepanjang masih terjadi interaksi

23.

5 Soerjono Soekanto, Sosiologi Suatu Pengantar. PT. RajaGrafindo Persada.Jakarta, 2002), h.

6 Soerjono Soekanto, Ibid., h. 305

7 Piotr Sztompka, Sosiologi Perubahan Sosial, (Penterjemah; Alimandan.Jakarta: Prenada Media Group, 2008), h. 3. 
antarmanusia dan antarmasyarakat. Perubahan sosial terjadi karena adanya perubahan dalam unsur-unsur yang mempertahankan keseimbangan masyarakat, seperti perubahan dalam unsur-unsur geografis, biologis, ekonomis, dan kebudayaan.

Perubahan sosial benar-benar ada atau tidak, tentu harus dilihat dari berbagai teori yang ada.Adapun teori-teori yang menjelaskan mengenai perubahan sosial sebagai berikut.

\section{Teori Evolusi (Evolution Theory)}

Teori ini pada dasarnya berpijak pada perubahan yang memerlukan proses yang cukup panjang. Dalam proses tersebut, terdapat beberapa tahapan yang harus dilalui untuk mencapai perubahan yang diinginkan. Polak menyebut evolusi dengan perkembangan. ${ }^{8} \mathrm{Ada}$ bermacam-macam teori tentang evolusi.Teori tersebut digolongkan ke dalam beberapa kategori, yaitu unilinear theories of evolution, universal theories of evolution, dan multilined theories of evolution. Unilinear

\section{Theories of Evolution}

Teori ini berpendapat bahwa manusia dan masyarakat termasuk kebudayaannya akan mengalami perkembangan sesuai dengan tahapantahapan tertentu dari bentuk yang sederhana ke bentuk yang kompleks dan akhirnya sempurna. Pelopor teori ini antara lain Auguste Comte dan Herbert Spencer. ${ }^{9}$

2. Universal Theories of Evolution

Teori ini menyatakan bahwa perkembangan masyarakat tidak perlu melalui tahap-tahap tertentu yang tetap.Kebudayaan manusia telah mengikuti suatu garis evolusi tertentu. Menurut Herbert Spencer, prinsip teori ini adalah bahwa masyarakat merupakan hasil perkembangan dari kelompok homogen menjadi kelompok yang heterogen. ${ }^{10}$

\section{Multilined Theories of Evolution}

Teori ini lebih menekankan pada penelitian terhadap tahap-tahap perkembangan tertentu dalam evolusi masyarakat.Misalnya mengadakan penelitian tentang perubahan sistem mata pencaharian dari sistem berburu ke sistem pertanian menetap dengan menggunakan pemupukan dan pengairan. ${ }^{11}$

Menurut Cohen teori evolusioner cenderung bersifat ethnocentris karena mereka menganggap masyarakat modern lebih hebat daripada masyarakatmasyarakat sebelumnya. ${ }^{12}$

\section{Teori Konflik (Conflict Theory)}

Menurut pandangan teori ini, pertentangan atau konflik bermula dari pertikaian kelas antara kelompok yang menguasai modal atau pemerintahan

8 Mayor Polak, Op. Cit., h. 387.

9 Soerjono Soekanto, Op. Cit.,311.

10Soerjono Soekanto, Ibid.,h. 312.

11 Soerjono Soekanto, Loc. Cit.

12 Bruce J. Cohen, Sosiologi Suatu Pengantar,(Penterjemah; Sahat Simamora,Jakarta: PT. Rineka Cipta, 1992), h. 454. 
dengan kelompok yang tertindas secara materiil, sehingga akan mengarah pada perubahan sosial. Teori ini memiliki prinsip bahwa konflik sosial dan perubahan sosial selalu melekat pada struktur masyarakat. ${ }^{13}$

Teori ini menilai bahwa sesuatu yang konstan atau tetap adalah konflik sosial, bukan perubahan sosial.Karena perubahan hanyalah merupakan akibat dari adanya konflik tersebut. Karena konflik berlangsung terus-menerus, maka perubahan juga akan mengikutinya. Dua tokoh yang pemikirannya menjadi pedoman dalam Teori Konflik ini adalah Karl Marx dan Ralf Dahrendorf.

Sunarto berpendapat bahwa yang menonjol dari teori konflik adalah teori ketergantungan.Teori ketergantungan merupakan teori yang mendasarkan pada pengalaman negara-negara Latin perkembangan dunia tidak merata; Negaranegara industri menduduki posisi dominan sedangkan Negara-negara Dunia Ketiga $^{14}$ secara ekonomis tergantung padanya. Perkembangan Negara-negara industri dan keterbelakangan Dunia-dunia Ketiga, menurut teori ini berjalan bersamaan: di kala Negara-negara industri mengalami perkembangan, maka Negara-negara Dunia Ketiga mengalami kolonialisme dan neokolonialisme, kusus di Amerika Latin, tidak mengalami "tinggal landas" tetapi justru semakin terbelakang.

\section{Teori Fungsionalis (Functionalist Theory)}

Konsep yang berkembang dari teori ini adalah cultural lag (kesenjangan budaya). Konsep ini mendukung Teori Fungsionalis untuk menjelaskan bahwa perubahan sosial tidak lepas dari hubungan antara unsur-unsur kebudayaan dalam masyarakat.Menurut teori ini, beberapa unsur kebudayaan bisa saja berubah dengan sangat cepat sementara unsur yang lainnya tidak dapat mengikuti kecepatan perubahan unsur tersebut.Maka, yang terjadi adalah ketertinggalan unsur yang berubah secara perlahan tersebut.Ketertinggalan ini menyebabkan kesenjangan sosial atau cultural lag.

Para penganut Teori Fungsionalis lebih menerima perubahan sosial sebagai sesuatu yang konstan dan tidak memerlukan penjelasan.Perubahan dianggap sebagai suatu hal yang mengacaukan keseimbangan masyarakat. Proses pengacauan ini berhenti pada saat perubahan itu telah diintegrasikan dalam kebudayaan. Apabila perubahan itu ternyata bermanfaat, maka perubahan itu bersifat fungsional dan akhirnya diterima oleh masyarakat, tetapi apabila terbukti disfungsional atau tidak bermanfaat, perubahan akan ditolak. Tokoh dari teori ini adalah William Ogburn. berikut.

Secara lebih ringkas, pandangan Teori Fungsionalis adalah sebagai

\section{${ }^{13}$ Loc. Cit.}

14 Sunarto menyebutkan istilah-istilah tersebut antara lain; Istilah masyarakat Dunia Ketiga mengacu kepada masyarakat dunia yang pernah dijajah oleh Negara-negara Barat dan yang masyarakatnya kebanyakan hidup dari pertanian. Istilah masyarakat Dunia Pertama (first World Societies) mengacu pada Negara-negara industri maju di Eropa Barat, Amerika, Australia, dan Jepang. Istilah masyarakat Dunia Kedua (Second World Societies) mengacu pada negara-negara industry di Eropa Timur.Negara-negara "Sedang Berkembang" tersebut sering pula dijuluki Negara-negara Selatan (South Countries), karena negara-negara tersebut terletak di belahan Selatan bumi. 
1. Setiap masyarakat relatif bersifat stabil.

2. Setiap komponen masyarakat biasanya menunjang kestabilan masyarakat.

3. Setiap masyarakat biasanya relatif terintegrasi.

4. Kestabilan sosial sangat tergantung pada kesepakatan bersama (konsensus) di kalangan anggota kelompok masyarakat.

Yang terkenal dari teori fungsionalis ini adalah teori modernisasi. Teori modernisasi megnanggap bahwa Negara-negara terbelakang akan menempuh jalan yang sama dengan Negara industri maju di Barat sehingga kemudian mengalami perkembangan pula melalui proses modernisasi. ${ }^{15}$ Selebih jauh lagi menurutnya teori ini berpandangan bahwa masyarakt-masyarakat yang belum berkembang perlu mengatasi berbagai kekurangan dan masalahnya sehingga mencapai tahap "tinggal landas" (take-off) ke arah perkembangan ekonomi.

\section{Teori Siklis (Cyclical Theory)}

Teori ini mencoba melihat bahwa suatu perubahan sosial itu tidak dapat dikendalikan sepenuhnya oleh siapapun dan oleh apapun.Karena dalam setiap masyarakat terdapat perputaran atau siklus yang harus diikutinya.Menurut teori ini kebangkitan dan kemunduran suatu kebudayaan atau kehidupan sosial merupakan hal yang wajar dan tidak dapat dihindari. Sementara itu, beberapa bentuk Teori Siklis adalah sebagai berikut :

1. Teori Oswald Spengler (1880-1936)

Menurut teori ini, pertumbuhan manusia mengalami empat tahapan, yaitu anak-anak, remaja, dewasa, dan tua. Pentahapan tersebut oleh Spengler digunakan untuk menjelaskan perkembangan masyarakat, bahwa setiap peradaban besar mengalami proses kelahiran, pertumbuhan, dan keruntuhan. Proses siklus ini memakan waktu sekitar seribu tahun.

2. Teori Pitirim A. Sorokin (1889-1968)

Sorokin berpandangan bahwa semua peradaban besar berada dalam siklus tiga sistem kebudayaan yang berputar tanpa akhir.Siklus tiga sistem kebudayaan ini adalah kebudayaan ideasional, idealistis, dan sensasi.

a. Kebudayaan ideasional, yaitu kebudayaan yang didasari oleh nilai-nilai dan kepercayaan terhadap kekuatan supranatural.

b. Kebudayaan idealistis, yaitu kebudayaan di mana kepercayaan terhadap unsur adikodrati (supranatural) dan rasionalitas yang berdasarkan fakta bergabung dalam menciptakan masyarakat ideal.

c. Kebudayaan sensasi, yaitu kebudayaan di mana sensasi merupakan tolok ukur dari kenyataan dan tujuan hidup.

3. Teori Arnold Toynbee (1889-1975)

Toynbee menilai bahwa peradaban besar berada dalam siklus kelahiran, pertumbuhan, keruntuhan, dan akhirnya kematian.Beberapa peradaban besar menurut Toynbee telah mengalami kepunahan kecuali

15 Sunarto, Ibid.,217. 
peradaban Barat, yang dewasa ini beralih menuju ke tahap kepunahannya.

\section{Simpulan}

Dakwah itu pada hakikanya adalah Perubahan sosial. Perubahan sosial dimaksud adalah perubahan yang terjadi sebagai suatu variasi dari cara hidup yang telah diterima karena adanya perubahan kondisi geografi, kebudayaan material, komposisi penduduk, ideologi, maupun adanya difusi atau penemuanpenemuan baru dalam masyarakat. Dalam konteks dakwah, perubahan sosial adalah bagaimana merubah suatu kondisi fisik/materi, sumber daya, pengetahuan, budaya, keimanan dan ibadah suatu masyarakat lebih sempurna dari kondisi sebelumnya, dengan menggunakan pendekatan, strategi, dan metode yang sebelumnya telah dianalisa dengan menggunakan teori sosiologi.

\section{Referensi}

Al-Bayanuny, Syekh Muhammad Abu Al-Fattah (2010).Ilmu Dakwah; Prinsip Dan Kode Etik, (Penterj, Dedi Junaedi, Jakarta: Akademika Presindo

Aliyudin dan As, Enjang (2009), Dasar-Dasar Ilmu Dakwah: Pendekatan Filofofis dan Praktis, Widya Padjadjaran.

Aziz, Moh. Ali (2009). Ilmu Dakwah, Jakarta: Prenada Media Group,

Amin, Samsul Munir (2009). Ilmu Dakwah. Jakarta: Amzah.

Cohen, Bruce J. (1992). Sosiologi Suatu Pengantar. Jakarta: PT. Rineka Cipta

Khaldun, Ibn. (1986). Muqaddimah.Penterjemah; Ahmadi Thoha. Jakarta: Pustaka Firdaus.

Kuntjojo (2009).Filsafat Ilmu. Kedir: Program Studi Pendidikan Bimbingan Dan Konseling Universitas Nusantara PGRI.

Muhiddin, Asep (2002), Dakwah Dalam Perspektif Al-Qur'an, Bandung: Pustaka Setia.Moleong,

Polak, Mayor (1979). Sosiologi Suatu Buku Pengantar Ringkas. Jakarta: PT. Ichtiar Baru.

Salmadanis, (2004), Da'i Dan Kepemimpinan.Jakarta, The Minangkabau Foundation.Soekanto, Soerjono (2002). Sosiologi Suatu Pengantar. Jakarta: PT. RajaGrafindo Persada.

Sunarto, Kamanto (2004). Pengantar Sosiologi. Jakarta: Lembaga Penerbit Fakultas Ekonomi Universitas Indonesia.

Suriasumantri, Jujun S (2003). Filsafat Ilmu: Sebuah Pengantar Populer. Jakarta: Pustaka Sinar Harapan.

Sztompka, Piotr (2008). Sosiologi Perubahan Sosial. Jakarta: Prenada Media Group.

Tafsir, Ahmad (1997). Filsafat Umum: Akal dan Hati Sejak Thales Sampai James. Bandung:PT. Remaja Rosdakarya., 